\title{
PELAKSANAAN TANGGUNG JAWAB BANK TERHADAP NASABAH PENGGUNA KARTU ATM PADA BANK BRI CABANG RENON DENPASAR
}

\author{
Putu Bagus Bendesa Wirananda, Fakultas Hukum Universitas Udayana, e-mail: \\ Baguswirananda@gmail.com \\ Ni Putu Purwanti, Fakultas Hukum Universitas Udayana, e-mail: \\ putu_purwanti@unud.ac.id
}

doi: https://doi.org/10.24843/KS.2020.v08.i08.p12

\begin{abstract}
ABSTRAK
Anjungan Tunai Mandiri (ATM) merupakan suatu produk perbankan yang dapat memudahkan nasabah dalam melakukan transaksi keuangan. Tetapi disisi lain nasabah sebagai pengguna ATM, dapat mengalami kerugian akibat dari kerusakan mesin ATM. Tujuan dari penulisan ini untuk mengetahui perlindungan hukum bagi nasabah pengguna kartu ATM dan untuk mengetahui tanggungjawab bank terhadap nasabah yang mengalami kerugian dalam menggunakan kartu ATM. Metode penelitian yang digunakan adalah metode penelitian empiris. Hasil dari penulisan ini adalah Bank wajib memberikan perlindungan baik sebelum dan sesudah terjadinya transaksi dalam menggunakan ATM berdasarkan Surat Edaran Bank Indonesia Nomor. 14/17/DASP Tentang Penyelenggaraan Kegiatan Alat Pembayaran dengan Menggunakan Kartu (APMK) dan memberikan ganti rugi terhadap nasabah yang mengalami kerugian dari penggunaan ATM berdasarkan ketentuan-ketentuan dalam Undang-Undang Nomor 8 Tahun 1999 Tentang Perlindungan Konsumen.
\end{abstract}

Kata Kunci : Tanggung Jawab, Nasabah, ATM

\begin{abstract}
Automatic Teller Machine (ATM) is one of the banking products that can facilitate customer in conducting financial transaction activites. But on the other hand the customer, as an ATM product user, can suffer losses due to damage to the ATM machine The purpose of this paper is to find out the legal protection for customers who use ATM cards and to determine the bank's responsibility to customers who experience losses in using ATM cards. The research method used is the empirical method. The result of this study Banks are required to provide protection both before and after the transaction in using an ATM based on Bank Indonesia Circular Number. 14/17 / DASP Regarding the Implementation of Card-Based Payment Instrument Activities and provide compensation to customers who have suffered losses from the use of ATMs based on the provisions in Law Number 8 of 1999 Concerning Consumer Protection.
\end{abstract}

Key words : Responsibility, Customer, ATM

\section{Pendahuluan}

1.1. Latar Belakang

Bank merupakan lembaga yang memberikan layanan berbentuk simpanan, pinjaman, mengatur peredaran mata uang serta melakukan pengawasan terhadap mata uang, hingga penyimpanan benda berharga dan pembiayaan usaha. Selain itu bank 
tidak hanya mencari keuntungan tetapi juga pelayanan serta sosial, baik perseorangan, suatu Lembaga maupun perusahaan. ${ }^{1}$

Perbankan menyediakan dua bentuk jasa yaitu yang pertama suatu alat pembayaran yang efektif bagi nasabah dalam bentuk tabungan, uang tunai, kartu debit/kredit, dan yang lainya. Bentuk jasa yang kedua yaitu selaku instrument guna menaikkan aliran dana investasi kepada pemakaian yang menguntungkan, melalui penampungan dana milik nasabah yang disalurkan kepada pihak yang membutuhkan dana. ${ }^{2}$ Dalam ketentuan Pasal 4 Undang-Undang Nomor 10 Tahun 1998 Tentang Perbankan, Perbankan Indonesia bertujuan menunjang pelaksanaan pembangunan nasional dalam rangka meningkatkan pemerataan, pertumbuhan ekonomi rangka meningkatkan pemerataan, pertumbuhan ekonomi, dan stabilitas nasional kearah peningkatan kesejahteraan rakyat banyak.

Melalui perkembangan teknologi dan informasi yang pesat, dunia perbankan dapat menggunakan Teknologi Informasi (TI) dalam bidang perbankan untuk memaksimalkan pelayanan terhadap nasabahnya. Salah satu contoh perkembangan teknologi informasi yang diberikan oleh Bank adalah Anjungan Tunai Mandiri (selanjutnya disebut ATM). ATM dapat berperan sebagai pengganti "teller" yang dapat melayani berbagai transaksi perbankan. Dengan adanya ATM masyarakat dipermudah untuk melakukan transaksi yang membutuhkan jumlah yang cukup besar, dengan itu dapat mengurangi risiko yang terjadi apabila masyarakat mengalami kehilangan ataupun menjadi korban perampokan. ATM juga dapat mengakibatkan masalah bagi penggunanya. ${ }^{3}$

Dalam transaksi memakai kartu ATM, kerap kali hak-hak nasabah sebagai konsumen tidak terpenuhi dengan baik, sehingga menyebabkan kerugian bagi nasabah. Kerugian tersebut disebabkan karena : Uang yang tersedia dalam mesin ATM habis; Ada pengalihan fiktif, yaitu berupa pengambilan dana oleh pihak lain; Mesin ATM tidak beroperasi karena rusak; Uang tidak keluar dari mesin ATM, atau uang yang keluar dari mesin ATM hanya sebagian; Uang tidak diperoleh tetapi rekening terdebet ; Transaksi satu kali tetapi rekening terdebet dua kali; Uang yang keluar sobek. ${ }^{4}$ Hal tersebut setidaknya dapat dilihat dari pengaduan yang disampaikan oleh nasabah bank kepada OJK. Menurut data OJK semester I tahun 2015, terdapat 644 pengaduan yang diterima OJK dari para konsumen. Dari 644 pengaduan tersebut, sektor perbankan menyumbang pengaduan yang paling besar sebanyak 390 pengaduan atau $60,5 \%$ dari keseluruhan pengaduan. ${ }^{5}$

Bank sebagai pelaku usaha dalam melakukan usahanya wajib menjamin akan mutu jasanya, sesuai dengan pasal 7 huruf d Undang-undang Nomor 8 Tahun 1999 tentang Perlindungan Konsumen. Jika bank tidak menjamin mutu jasa pelayanannya,

1 Sembiring, Sentosa. Hukum Perbankan Edisi Revisi (Bandung, Mandar Maju, 2012), 2

2 Juniawan, Komang. "Perlindungan Hukum terhadap Nasabah Korban Kejahatan Penggandaan Kartu ATM pada Bank Swasta Nasional di Denpasar." Jurnal Magister Hukum Udayana 2, No.2 (2013): 2

3 Putra, A., Dahana, Cokorda. "Perlindungan Hukum Terhadap Rekening Nasabah Bank Dalam Perjanjian Penggunaan Anjungan Tunai Mandiri (ATM) Pada Bank Negara Indonesia (BNI) Cabang Teuku Umar Denpasar." Kertha Semaya 5, No.1 (2016): 2.

4 Muryatini, Ni."Perlindungan Hukum Bagi Nasabah Pengguna Anjungan Tunai Mandiri(ATM) dalam Sistem Perbankan Indonesia" Jurnal Magister Hukum Udayana 5 No.1 (2016): 119 - 130.

5 Nurdin, A. "Kajian Peraturan Perlindungan Konsumen di Sektor Perbankan." Jurnal Hukum dan Pembangunan 48 No.2 (2018): 299-322 
dapat dituntut untuk memberikan ganti rugi, sesuai dengan pasal 7 huruf $\mathrm{f}$ jo. Huruf $\mathrm{g}$ Undang-undang Nomor 8 Tahun 1999 tentang Perlindungan Konsumen.Berdasarkan situasi tersebut yang membawa Bank BRI cabang Renon Denpasar sebagai salah satu bank besar yang ada di Bali untuk melakukan fungsi dan peranan sesuai dengan yang diharapkan bagi masyarakat selaku nasabahnya.

\subsection{Rumusan Masalah}

Berdasarkan latar belakang tersebut, permasalahan yang akan dibahas adalah sebagai berikut :

1. Bagaimanakah bentuk perlindungan hukum terhadap nasabah atas kerugian akibat dari penggunaan kartu ATM pada Bank BRI Cabang Renon?

2. Bagaimanakah pertanggungjawaban Bank BRI cabang Renon Denpasar terhadap nasabah yang mengalami kerugian dalam menggunakan ATM?

\subsection{Tujuan Penulisan}

Adapun tujuan dari penulisan artikel ini untuk mengetahui bentuk perlindungan hukum terhadap nasabah atas kerugian akibat dari penggunaan kartu ATM pada Bank BRI Cabang Renon serta untuk mengetahui tanggung jawab bank BRI cabang Renon Denpasar terhadap nasabah yang mengalami kerugian dalam menggunakan ATM

\section{Metode Penelitian}

Jenis penelitian yang dipakai yakni penelitian hukum empiris, yaitu data yang diperoleh langsung dari masyarakat sebagai sumber pertama melalui penelitian lapangan, yang dilakukan melalui pengamatan, wawancara ataupun penyebaran kuisioner dan data yang diperoleh dari kepustakaan sebagai sumber kedua. ${ }^{6}$ Pendekatan yang dipakai yakni pendekatan kasus (case approach) dan pendekatan perundang-undangan (The Statue Approach). Dalam studi ini memakai dua jenis data,yakni data primer dan data sekunder. Bagi data primer, Teknik pengambilan datanya dilakukan dengan mengadakan wawancara (interview) langsung dengan staff bagian hukum Bank BRI cabang Renon kota Denpasar. Sedangkan untuk data sekunder, Teknik pengambilan data dilakukan dengan studi dokumen,yaitu dengan cara mengumpulkan materi-materi hukum dokumen-dokumen yang relevan yang selanjutnya di klasifikasikan secara sistematif sesuai dengan kebutuhan penelitian. Dari data yang berhasil dikumpulkan kemudian dianalisa memakai teknik pengolahan data secara kualikatif, yakni memilih data sesuai dengan kualitasnya dalam rangka menjawab suatu permasalahan penelitian. Selanjutnya data tersebut dituangkan secara deskriptif analis, serta menyusun dan menguraikannya secara sistematis.

\section{Hasil dan Pembahasan}

3.1 Bentuk Perlindungan Hukum Terhadap Nasabah Atas Kerugian Akibat Dari Penggunaan Kartu ATM Pada Bank BRI Cabang Renon

Bank merupakan suatu lembaga keuangan yang memegang peran vital dalam perekonomian Indonesia yang sudah banyak menerapkan kemajuan teknologi yang

6 Marzuki, Peter Mahmud. Penelitian Hukum Edisi Revisi (Jakarta, Prenada Media Group,2017), 133. 
berkenaan dengan kehidupan sehari-hari masyarakat.7 Kemajuan teknologi informasi ini memicu pertumbuhan pembayaran memakai kartu ATM berupa kartu kredit dan atau kartu debit dengan fasilitas transfer uang secara elektronik yang sudah menjamur di kalangan masyarakat karena pemakaiannya yang sangat praktis. Namun dibalik semua kemudahan itu, terdapat masalah yang merugikan nasabah pengguna kartu ATM sebagai contoh kegagalan saat transaksi penarikan tunai, uang tidak keluar dari mesin ATM tetapi rekening saldo nasabah ikut berkurang, pendobelan dan pembobolan rekening hingga nomor call center palsu dan masih banyak kasus lainnya. ${ }^{8}$

Nasabah selaku konsumen pengguna kartu ATM perlu memperoleh suatu perlindungan. Perlindungan terhadap nasabah bank benar-benar diperlukan agar posisinya selaku konsumen tidak lebih rendah jika dibandingkan posisi pelaku usaha atau pihak bank. Ketika suatu perjanjian kredit yang dibuat oleh pihak bank, biasanya berbentuk perjanjian baku, dimana dalam perjanjian tersebut muatannya sudah ditetapkan secara sepihak oleh pihak bank. Dalam suatu perjanjian kredit yang dibuat oleh bank, yang umumnya berupa perjanjian baku, isinya sudah ditetapkan secara sepihak oleh bank. Pihak nasabah tidak mempunyai pilihan untuk menandatangani perjanjian tersebut. Sehingga demi tercapainya suatu keseimbangan kedudukan antara pihak bank dan nasabah dibutuhkan adanya suatu perlindungan terhadap nasabah selaku konsumen.

Pengamanan berupa payung hukum tersebut diatur di dalam Undang-Undang Nomor 10 Tahun 1998 Tentang Perbankan Pasal 29 ayat (5) yang menentukan :“Untuk kepentingan nasabah, Bank menyediakan informasi mengenai kemungkinan timbulnya resiko kerugian bagi transaksi nasabah yang dilakukan melalui Bank". Dalam pasal tersebut tersirat adanya perlindungan hukum terhadap nasabah Bank namun tidak diberikan pemahaman dan penjelasan secara lebih detail tentang apa dan bagaimana kepentingan nasabah yang tidak boleh dirugikan.

Berdasarkan kasus tersebut Bank Indonesia mengeluarkan Surat Edaran Bank Indonesia Nomor 14/17DASP pada tanggal 7 Juni 2012 menyebutkan bahwa pelaku usaha dan penerbit kartu ATM lebih meningkatkan keamanan dalam pelaksanaan serta pengawasan atas fasilitas bagi nasabah sehingga tidak terjadinya kerugian dan adanya kepastian hukum bagi nasabah. Dalam Surat Edaran Bank Indonesia Nomor 14/17DASP tentang Penyelenggaraan Kegiatan Alat Pembayaran dengan Menggunakan Kartu (APMK) mengatur Bank penerbit APMK memiliki kewajiban untuk:

1. Menjelaskan dan menyampaikan informasi secara tertulis dengan penggunaan Bahasa Indonesia yang mudah dimengerti serta sejelas-jelasnya, ditulis menggunakan huruf serta angka yang dapat terbaca dengan mudah bagi calon pemegang kartu

2. Memberikan informasi tentang nomor telepon atau call center yang dapat dihubungi untuk memverifikasi mengenai keabsahan fasilitas yang diberikan dan atau informasi yang disalurkan oleh penerbit.

7 Witasari, Aryani., Setiono Aris. "Perlindungan Hukum Pengguna Jasa Electronic Banking(EBanking) Di Tinjau Dari Perspektif Hukum Pidana Di Indonesia" Jurnal Pembaharuan Hukum 2, No.1 (2015): 127

8 Meilianasari, Yeni. " Analisis Kepercayaan Nasabah Pengguna ATM" Jurnal Manajemen Bisnis 2, No.1 (2013): 29. 
Disamping itu Surat Edaran Bank Indonesia Nomor 14/17/DASP mewajibkan penerbit kartu ATM memberikan informasi secara tertulis ke calon pemegang kartu, yaitu :

1. Prosedur dan cara dalam menggunakan kartu ATM/Kredit/Debit, fasilitas yang menempel pada kartu ATM/Kredit/Debit, dan akibat yang mungkin muncul dari pemakaian kartu ATM/Kredit/Debit.

2. Hak dan kewajiban pemegang kartu ATM/Debit yaitu:

a) Hal-hal penting yang wajib diperhatikan oleh pemegang kartu dalam hal penggunaan kartu, termasuk berbagai resiko/konsekuensi yang ada dari penggunaan kartu ATM/Kredit/Debit.

b) Hak serta tanggung jawab pemegang kartu dan penerbit kartu ATM/Debet jika timbul hal yang menghasilkan kerugian kedua belah pihak.

c) Besaran biaya dan jenis biaya yang dikenakan penerbit.

d) Prosedur serta konsekuensi yang ada bila pengguna kartu ATM/Kredit/Debit tidak lagi berkeinginan menjadi pengguna kartu ATM/Kredit/Debit.

Menurut Bapak A.A Yogi S Staf Bagian Hukum Bank BRI Renon hak dan kewajiban Bank BRI sebagai pencetak kartu ATM yaitu: ${ }^{9}$

1. Hak Bank BRI sebagai penerbit kartu ATM yaitu :

a) Bank untuk keperluannya sendiri berhak untuk meminta informasi data profil nasabah sesuai dengan kebutuhannya dan sesuai peraturan yang berlaku.

b) Bank berhak meminta dokumen pendukung kepda nasabah sesuai dengan keperluannya

c) Bank berhak mengenakan tarif dan biaya atas penggunaan sebuah layanan yang nantinya disesuaikan dengan jenis rekening.

2. Kewajiban Bank BRI sebagai penerbit kartu ATM :

a) Bank akan memberikan nomor sandi pribadi/personal idemtification number (PIN) kepada pemegang kartu ATM dan pemegang kartu ATM wajib menjaga rahasia pin dan tidak boleh memberitahukan kepada siapapun termasuk kepada petugas bank.

b) Bank memberikan informasi secara jelas kepada pemegang kartu ATM tentang bagaimana cara bertransaksi menggunakan ATM.

c) Bank dapat mengirimkan dan atau menerbitkan laporan rekening kepada nasabah setiap bulannya atau dengan rentang waktu tertentu sebagaimana yang dianggap sesuai oleh pihak bank.

d) Bank akan sesegera mungkin memberitahu nasabah apabila ditemukan adanya suatu kekeliruan dalam setiap bentuk komunikasi kepada nasabah yang mempengaruhi isi saldo pada rekening nasabah. (wawancara tanggal 25 Mei 2019)

Berdasarkan hasil wawancara dengan Bapak A.A Yogi S Staf Bagian Hukum Bank BRI Renon, yang dilakukan Bank BRI dalam memberikan upaya perlindungan dan pengamanan untuk nasabah pengguna kartu ATM mengacu pada SE26DIR/HKM/04/2019 yang mengatur operasional prosedur Bank BRI. Bank BRI selalu menjamin dan menjaga hak-hak nasabah sejalan dengan dengan pasal 1 UndangUndang Perbankan, karena Bank berkewajiban untuk menjaga rahasia nasabah

9 Wawancara dilaksanakan pada tanggal: 25 Mei 2019, Bertempat di Bank BRI Cabang Renon Kota Denpasar. 
penyimpan dan simpanannya. Jadi perlindungan hukum terhadap nasabah pengguna ATM bisa dilakukan sebelum dan sesuah terjadinya transaksi .(wawancara tanggal 25 Mei 2019)

Menurut Bapak A.A Yogi S Staf Bagian Hukum Bank BRI Renon, pengamanan yang telah diberikan oleh Bank BRI untuk melindungi nasabah yaitu:

1. Pengamanan Internal

Pengamanan ini hanya melibatkan pihak Bank sendiri tanpa melibatkan nasabah untuk berperan aktif. Pengamanan ini meliputi pemantauan terhadap sistem yang digunakan pada mesin ATM, yang meliputi :

a) Pemantauan seluruh transaksi secara Online oleh Bagian Operasional TSI.

b) Pengawasan terhadap fungsi dari perangkat keras (Hardware) secara online.

c) Pengawasan terhadap sistem (Software) yang digunakan untuk pengoperasian mesin ATM secara online.

d) Pengawasan terhadap jaringan (Network) yang digunakan dalam transaksi ATM secara online.

e) Pengawasan terhadap jumlah uang dalam mesin ATM secara online.

f) Pengawasan terhadap kertas pencatat transaksi (Journal Roll) secara online. Dengan pengawasan sistem secara online, bila terjadi kerusakan pada sistem ATM, pihak ATM akan mengetahuinya dan segera memperbaiki kerusakan pada sistem ATM tersebut.

2. Pengamanan Eksternal

Pengamanan ini melibatkan nasabah untuk turut serta secara aktif menjaga keamanan tersebut. Bentuk pengamanan eksternal mengenai perlindungan teknis yang diberikan oleh Bank yaitu berupa:

a) Pemberian PIN untuk nasabah pengguna kartu ATM yang bisa diganti nomornya sesuai keinginan pemegang kartu.

b) Seandainya pemegang kartu keliru atau salah memasukan nomor PIN sejumlah tiga kali maka otomatis kartu akan terblokir. (wawancara tanggal 25 Mei 2019)

Undang-Undang Nomor 8 Tahun 1999 Tentang Perlindungan Konsumen diharapkan bisa menjadi pedoman atau dasar hukum atas perlindungan bagi nasabah pengguna kartu ATM yang merasa dirugikan. Nasabah pengguna kartu ATM adalah konsumen seperti yang dijelaskan pada Pasal 1 angka 2 UUPK mengenai pengertian "konsumen" yaitu, "setiap orang pemakai barang dan/atau jasa yang tersedia dalam masyarakat, baik bagi kepentingan diri sendiri, keluarga, orang lain maupun makhluk hidup lain, dan tidak untuk diperdagangkan".

Apabila saat menggunakan ATM terjadi masalah yang mengakibatkan kerugian bagi nasabah yang bukan karena kesalahannya maka pihak bank wajib memberikan ganti rugi seperti yang diatur dalam UUPK Pasal 7 huruf $f$ dan huruf g yang berbunyi: "Memberi kompensasi, ganti rugi dan/atau penggantian atas kerugian akibat penggunaan, pemakaian dan pemanfaatan barang dan/atau jasa yang diperdagangkan. Memberi kompensasi, ganti rugi dan/atau penggantian apabila 
barang dan/atau jasa yang diterima atau dimanfaatkan tidak sesuai dengan perjanjian". 10

Problema yang sering terjadi di masyarakat, kurangnya pengetahuan mengenai tanggung jawab yang diatur dalam UUPK. Selain itu nasabah juga tidak mengerti mengenai hak dan kewajiban sebagai nasabah jika timbul kerugian di kemudian hari dalam pemakaian ATM. Hal ini terjadi karena minimnya sosialisasi mengenai norma hukum yang terjadi di masyarakat. Penyelesaian sebuah masalah bagi nasabah pengguna kartu ATM tidak hanya menunjuk di peradilan tapi bisa diselesaikan diluar peradilan sesuai pada pasal 45 ayat (1) UUPK.

Dalam menjalankan tugasnya demi memberikan perlindungan terhadap konsumen dan masyarakat, Otoritas Jasa Keuangan bekerja berdasarkan Peraturan Otoritas Jasa Keuangan yang mengoperasikan suatu hal secara spesifik. Dalam hal melindungi kepentingan konsumen dan masyarakat peraturan yang digunakan adalah Peraturan Otoritas Jasa Keuangan Nomor 1/POJk.07/2013 Tentang Perlindungan Konsumen Jasa Keuangan (selanjutnya disebut POJK) dimana memuat aturan-aturan yang memusatkan kewajiban bank bagi nasabahnya guna melindungi nasabah dari berbagai aktivitas bank, nasabah selalu menjadi pihak yang lebih rendah kedudukannya, sehingga pihak bank dapat memaksakan kehendaknya dalam syaratsyarat pada suatu perjanjian dalam bentuk perjanjian baku. ${ }^{11}$

Berdasarkan ketentuan pada Pasal 29 POJK, yakni pihak bank, diwajibkan untuk memberi ganti rugi kepada konsumen, yaitu nasabah yang dirugikan dalam bertransaksi melalui mesin ATM. Ketentuan tersebut sudah sesuai dengan ketentuan mengenai pertanggung jawaban dalam memberikan ganti rugi Pasal 1365 KUHPerdata dan pasal 1367 KUHPerdata.

\subsection{Pertanggungjawaban Bank BRI Renon Terhadap Nasabah Yang Mengalami Kerugian Dalam Bertransaksi Menggunakan ATM}

Penggunaan kartu ATM di Indonesia adalah suatu kegiatan yang sudah lumrah dilakukan oleh seluruh lapisan masyarakat, hal ini dikarenakan nasabah yang diwajibkan memiliki kartu ATM pada saat pertama kali membuka atau membuat rekening baru.12 Sehingga dari waktu ke waktu, jumlah nasabah yang aktif menggunakan ATM semakin meningkat, namun permasalahan tersebut menimbulkan pihak-pihak yang melakukan tindakan yang tidak bertanggungjawab dan memanfaatkan keadaan ini untuk melakukan tindak kejahatan. Beberapa permasalahan yang sering terjadi yaitu kartu ATM tertelan, sejumlah uang yang di tarik tidak sesuai, serta rekening yang terdebet namun tidak muncul sejumlah uang yang diterima.

Sebagai salah satu contoh kelemahan mesin ATM dapat dicontohkan berdasarkan pengalaman yang diderita Yusi Fitria yang merupakan nasabah Bank BRI. Tanggal 16 Agustus dia melakukan tarik tunai di mesin ATM Bank BRI Universitas Bengkulu. Hari itu mesin ATM sangat lama memproses, sekitar 3 menit dia menunggu tiba-tiba kartu atm nya keluar dan tertulis gangguan jaringan. Karena tidak ada tanda-tanda mesin

10 Prabawa, ida., Ariana, I. "Lembaga Perlindungan Hukum Bagi Nasabah Bank Pengguna Automated Teller Machine" Kertha Semaya 4, No.3 (2016):4.

11 Liewellyn, Felix., Dharmawan, N., Purwanti, N. 'Tanggung Jawab Bank Terhadap Nasabah Terkait Penarikan Uang Palsu Pada ATM." Kertha Semaya 8, No.1 (2019): 1-15.

12 Wintara, I., Dharmawan, N., Purwanti, N. "Mekanisme Pencegahan Kerugian dan Hak Nasabah Terkait Penggunaan Kartu Anjungan Tunai Mandiri (ATM)." Kertha Semaya 7, No.5 (2019): 1-14. 
akan kembali normal, dia memutuskan untuk pergi. Setelah keluar dari mesin atm, tibatiba ada sms banking masuk dan menyatakan bahwa ada penarikan tunai sebesar Rp.500.000. dia langsung balik ke bank dan menemui security. Dia sempat bertanya dan menjelaskan kronologi kejadian namun dia kecewa dengan tanggapan sequrity yang menganggap enteng dan menyebutkan hal itu sering terjadi. Malam harinya dia langsung menelpon call center BRI dan mendapat nomor pengaduan dan harus menunggu maksimal 14 hari kerja. ${ }^{13}$

Menurut Bapak A.A Yogi S, jika nasabah mengalami kendala atau kerugian dalam bertransaksi menggunakan ATM khusus nya penarikan tunai, nasabah dapat melaporkan ke call center yang ada di outlet ATM atau bertemu dengan customer service pada bank BRI terdekat. Beliau menambahkan, Bank BRI dalam menerima pengaduan dari nasabah, Bank BRI mempunyai system yang bernama BRICare. BRI care tersebut terkoneksi dengan system di kantor pusat yang akan menindaklanjuti pengaduan tersebut dalam tempo 3 hari kerja. Setelah ada balasan dari BRIcare maka dapat dipastikan penyebab dari permasalahan yang diadukan tersebut. (wawancara tanggal 25 Mei 2019).

Selain kerugian yang dialami nasabah karena kerusakan pada mesin ATM, ada juga kerugian yang dialami karena pihak ketiga atau kejahatan contohnya kasus pembobolan rekening atau skiming. Skimming adalah salah satu bentuk kejahatan yang memanfaatkan teknologi informasi untuk mencuri data berharga dan informasi mengenai kartu ATM dengan cara menyalin informasi pada strip magnetic kartu tersebut secara illegal dan tidak dibenarkan dimata hukum. ${ }^{14}$

Sebagai salah satu contoh kasus skimming yang dialami oleh Reza seorang mahasiswa di kota Solo. Awalnya dia ingin membayar uang spp kampus, tanggal 22 Juli 2019 dia iseng-iseng melihat saldo ATM nya melalui mobile banking ternyata sisa saldo nya hanya Rp.2000 dari yang awalnya Rp.7.000.000. dirinya mengira bahwa berkurangnya sejumlah uang tersebut disebabkan oleh cut off autodebet yang dilakukan otomatis guna melakukan pembayaran uang kuliah semester berikutnya, namun ia tersadar biasanya pemotongan otomatis oleh pihak kampus dilakukan setiap tanggal 23 Juli 2019. Merasa ada hal yang terjadi tidak sebagaimana mestinya, Reza mencetak mutasi rekening untuk mengetahui jejak transaksinya, dan hal yang terjadi adalah dalam kurun waktu beberapa hari sebelum kejadian, ternyata ada transaksi penarikan yang mana pemilik rekening tidak pernah melakukan hal tersebut. Hingga Reza pada akhirnya datang ke bank dan mendapati dirinya menjadi korban skimming, dimana terjadi pengambilan tunai mencurigakan yang sebelumnya terjadi di Medan dan Batam. ${ }^{15}$

Menurut Bapak A.A Yogi S, Skimming ini merupakan salah satu kejahatan perbankan dan rata-rata pelakunya adalah WNA Bulgaria. Apabila ada indikasi skimming maka dapat dipastikan uang nasabah yang hilang akan diganti oleh Bank BRI (terindikasi korban skimming). Namun apabila transaksi yang dilakukan oleh nasabah/pelaku kejahatan itu termaasuk dalam transaksi sukses, artinya kode atm dan

13 Yusi Fitria, 2018, "Saldo Terpotong, Uang Tidak Keluar Daei Mesin Tarik Tunai BRI", URLhttp://www.mediakonsumen.com, diakses tanggal 10 Agustus 2019

14 Sumbodo, Mugiatno., Fernas Jafar. "Skimming, Cara Kerja Dan Pencegahan Pada ATM." Jurnal Sains E Teknologi 3, No. 2 (2019): 11-16.

15 Bayu Galih Permana, 2019, “Duit Buat Bayar Kuliah Ludes Di ATM, Cerita Mahasiswa Korban Ini Menjadi Viral”, URL : http://www.hai.grid.id,diakses tanggal 2 Agustus 2019. 
pin atm cocok maka tidak akan di ganti oleh Bank BRI karena itu berarti adanya pin yang bocor. (wawancara tanggal 25 Mei 2019)

Berdasarkan penerapan hukum di Indonesia, nasabah selaku konsumen dianjurkan untuk mengajukan suatu gugatan kepada pihak yang mengakibatkan kerugian. Bentuk kualifikasi gugatan yang bisa diajukan yaitu adanya tindakan kecurangan atau disebut dengan wanprestasi yang termasuk dalam tindakan melawan hukum. Pada hal gugatan, jika terjadi wanprestasi artinya ada hubungan kontraktual diantara nasabah dan bank. Jika tidak ada hubungan kontraktual antara nasabah dan bank, sehingga pelaku usaha tidak memiliki tanggung jawab (hukum) kepada nasabah atau dapat dikatakan bahwa "tidak ada hubungan kontraktual, tidak ada tanggung jawab". 16

Namun pengugatan atas dasar perbuatan yang melawan hukum, ada atau tidaknya kaitan kontraktual tidaklah disyaratkan, maka daripada itu nasabah wajib mengumpulkan bukti adanya unsur-unsur :

1. Adanya perbuatan melawan hukum

2. Adanya kesalahan atau kelalaian pelaku usaha

3. Adanya kerugian yang dialami oleh konsumen dalam hal ini nasabah

4. Adanya hubungan kausal antara perbuatan melawan hukum dan kerugian yang dialami oleh konsumen

Menurut Bapak A.A YogiS, dalam praktek perbankan, masalah yang timbul antara bank dengan nasabah terjadi pada saat transaksi atau setelah transaksi selesai dilakukan. Permasalahan yang terjadi dapat disebabkan kelalaian nasabah itu sendiri maupun berasal dari pihak luar nasabah termasuk dalam hal ini pihak bank. Permasalahan yang terjadi dalam praktek perbankan khususnya jasa-jasa perbankan antara bank negeri maupun bank swasta meniliki banyak kesamaan. Jenis-jenis permasalahan yang ada dalam praktek perbankan yaitu:

1. Jasa penghimpun dana

a) Buku tabungan atau kartu ATM hilang

b) Pembobolan melalui ATM

c) Transaksi melalui mesin ATM uang tidak keluar tetapi saldo terdebet

d) Uang yang keluar jumlahnya tidak sesuai

e) Kesalahan penghitungan bunga deposito

f) Cek kosong

2. Jasa Penyaluran Kredit

a) Prosedur kredit yang bertele-tele

b) Keberatan atas angsuran yang harus dibayar

c) Keberatan atas kenaikan bunga pinjaman

d) Penyalahgunaan kartu kredit (wawancara tanggal 25 Mei 2019)

Selain itu terdapat masalah atau kasus lain mengenai ATM, contohnya penipuan memenangkan undian hadiah berupa uang, mobil, atau barang-barang mewah lainnya, yang mengatasnamakan sebuah Lembaga/perusahaan ternama, yang dimana si penipu meminta korban mentransferkan sejumlah uang sebagai biaya administrasi dan pajak ke penipu melalui nomor rekening miliknya, sudah tentu korban menggunakan ATM, karena ATM sangat mudah digunakan untuk melakukan transaksi pengiriman uang dan tidak butuh waktu lama seperti antri di teller. Secepat kilat uang korban melayang, dan hadiah yang dijanjikan penipu tidak kunjung datang. Selain itu beberapa modus

16 Slamet, Sri Redjeki. "Tuntutan Ganti Rugi dalam Perbuatan Melawan Hukum: Suatu Perbandingan dengan Wanprestasi." Lex Jurnalica 10, No. 2 (2013): 111 
lainnya seperti membobol card rider anti vandal atau lumrahnya dikenal sebagai tempat memasukan kartu ATM pada mesin, menempel nomor call center palsu, memasukan tusuk gigi pada card rider dan modus menukar kartu ..$^{17}$

Pelayanan aduan konsumen oleh pelaku jasa keuangan diatur dalam Surat Edaran Otoritas jasa Keuangan Nomor 2/SEOJK.07./2014 yang menghendaki bank menyelesaikan pengaduan nasabah sesuai tata cara penerimaan, penanganan dan pemantauan. Adapun mekanisme dalam penyelesaian pengaduan nasabah adalah: 18

1. Pihak perbankan diwajibkan melayani serta menyelesaikan jika terdapat pengaduan nasabah secepatnya sebelum pengaduan tersebut diketahui pihak lain

2. Pihak perbankan dalam melaksanakan pengaduan nasabah wajib menyelesaikannya secepatnya dengan kurun waktu 20 hari kerja sejak hari pengaduan diterima

3. Pihak bank wajib mempunyai tahapan pelayanan dan penyelesaian pengaduan yang mencakup prinsip aksebilitas, efisiensi, keadilan, efektifitas dan independensi.

4. Perlakuan yang objektif dan seimbang terhadap setiap pengaduan wajib diberikan oleh pihak bank. Bank wajib memberikan waktu yang cukup kepada nasabah dalam memaparkan isi dari pengaduannya serta memberikan kesempatan kepada pihak lain yang mempunyai kepentingan atas pengaduan (jika ada).

5. Pernyataan maaf serta menawarkan redress / remedy atau ganti rugi kepada nasabah wajib dilakukan oleh pihak bank. Ganti rugi sebagaimana dimaksud, harus memenuhi adanya pengaduan yang berisi tuntutan ganti rugi, kemudian pengaduan tersebut adalah benar adanya kerugian material serta konsumen sudah smemenuhi semua kewajibannya.

Permasalahan-permasalahan yang terjadi antara bank dengan nasabahnya pada prakteknya akan dilakukan dengan melalui penyelesaian tingkat internal. Awalnya pengaduan dari nasabah yang mengalami permasalahan tersebut kepada pihak bank, selanjutnya pihak bank akan melakukan penelitian dan pemeriksaan terhadap masalah tersebut dan selanjutnya memberikan solusi atas permasalahan tersebut kepada nasabah tersebut. Dalam penyelesaian masalah kartu ATM antara Bank dengan nasabah, ada beberapa cara yang bisa dilakukan nasabah antara lain $:^{19}$

1. Negosiasi

Negosiasi dilakukan melalui tawar menawar untuk mendapatkan keputusan, seperti pilihan terbaik agar sengketa dapat terselesaikan. Negosiasi diartikan sebagai sebuah usaha guna mencapai kompromi (perdamaian) yang menguntungkan kedua belah pihak yang bersengketa, yang pada awalnya memliki dua kepentingan bertentangan melalui suatu proses tawar menawar. Negosiasi merupakan salah satu alternatif dalam menyelesaikan sengketa

17 Mokoginta, Megi. "Perlindungan nasabah Bank Dari kejahatan Pembobolan ATM Menurut UU No.8 Tahun 1999 Tentang Perlindungan Konsumen." Lex privatum 4, No.6 (2016):100-107

18 Disemadi, Hari., Praningtyas, Paramita,. "Perlindungan Hukum Terhadap Nasabah Perbankan Pengguna CRM (Cash Recycling Machine)." Jurnal Magister Hukum Udayana 8, No.3 (2019): 386-402.

19 Suherman. "Upaya Mediasi Dalam Penyelesaian Sengketa Di Lembaga Perbankan." Jurnal Hukum Acara Perdata 4, No.1 (2018): 109-122. 
antara nasabah pengguna kartu ATM dan pihak bank. Prosedur penyelesaian sengketa yaitu :

a. Penyelesaian secara lisan

1) Melaporkan permasalahan melalui call center (pelayanan 24 jam). Call center merupakan fasilitas layanan nasabah yang disediakan oleh pihak bank penyedia jasa.

2) Langsung datang ke kantor cabang terdekat atau datang ke bank dimana pertama kali nasabah membuka rekening. Bagi nasabah yang mendapatkan kendala dalam penggunaan kartu ATM dapat menyelesaikan masalah dengan datang ke kantor cabang dimana ATM itu dibuat, hal ini dapat dikatakan pelayanan melalui agent atau customer service.

b. Penyelesaian yang dilakukan secara Tertulis

Penyelesaian ini dengan mengajukan surat kepada pimpinan bank, dimana nasabah mendatangi bank yang bersangkutan atau mengirim $e$ mail dengan melengkapi fotokopi identitas, bukti transaksi yang bersangkutan serta dokumen lain yang berhubungan dengan pengaduan yang disampaikan

c. Penerimaan pengaduan oleh bank

1) Bank menerima bagaimanapun jenis pengaduan oleh nasabah / perwakilan nasabah dalam bentuk lisan maupun tertulis

2) Selanjutnya bank menjelaskan tentang kebijakan kepada nasabah/perwakilan nasabah serta tahapan dalam melakukan pengaduan

3) Bank memberikan bukti atau tanda terima pengaduan yang telah diajukan secara tertulis.

2. Mediasi Perbankan

Penyelesaian pengaduan masalah melaui mediasi perbankan sesuai dengan Peraturan Bank Indonesia Nomor: 10/1/PBI/2008 tanggal 29 januari 2008 yang menjelaskan perihal mediasi perbankan, diantaranya:

a. Pengajuan melalui media tertulis berdasarkan format khusus dan dokumen yang dibutuhkan harus sudah memenuhi persyaratan.

b. Mediasi perbankan diajukan bersamaan dengan dokumen yang mendukung terkait sengketa kemudian diserahkan kepada Direktorat Investigasi dan Mediasi Perbankan Bank Indonesia.

\section{Kesimpulan}

Perlindungan hukum bagi nasabah pengguna ATM di Bank BRI Renon berupa perlindungan hukum preventif yang disediakan oleh pemerintah dalam bentuk peraturan Bank Indonesia yaitu memberikan prosedur dan pemahaman dalam menggunakan ATM dan perlindungan hukum represif yaitu melakukan pengaduan ke Bank jika nasabah mengalami kerugian dalam bertransaksi menggunakan ATM. Pertanggungjawaban terhadap nasabah yang mengalami kerugian saat bertransaksi menggunakan ATM bisa dilihat dari bentuk kesalahannya. Jika kesalahan tersebut disebabkan oleh mesin ATM yang rusak/error, maka pihak Bank akan memberikan ganti rugi sesuai dengan Undang-Undang Nomor 8 Tahun 1999 Tentang Perlindungan Konsumen, Undang-Undang Nomor 21 Tahun 2011 Tentang Otoritas Jasa Keuangan 
dan Peraturan Bank Indonesia Nomor:16/1/PBI/2014 namun apabila kesalahan dilakukan oleh nasabah seperti pin yang bocor atau lalai dalam bertransaksi menggunakan ATM maka Bank tidak akan mengganti kerugian yang dialami nasabah.

\section{DAFTAR PUSTAKA}

\section{Buku}

Sentosa, Sembiring. "Hukum Perbankan Edisi Revisi." (CV Mandar Maju, 2012).

Marzuki, Mahmud. Penelitian Hukum: Edisi Revisi. (Prenada Media, 2017).

\section{Jurnal}

Disemadi, Hari Sutra, and Paramita Prananingtyas. "Perlindungan Hukum Terhadap Nasabah Perbankan Pengguna CRM (Cash Recycling Machine)." Jurnal Magister Hukum Udayana (Udayana Master Law Journal) 8, no. 3 (2019): 286-402.

Juniawan, Komang. "Perlindungan Hukum Terhadap Nasabah Korban Kejahatan Penggandaan Kartu ATM Pada Bank Swasta Nasional di Denpasar." Jurnal Magister Hukum Udayana 2, no. 2 (2013): 44215.

Liewellyn, Felix, Ni Ketut Supasti Dharmawan, and Ni Putu Purwanti. "TANGGUNG JAWAB BANK TERHADAP NASABAH TERKAIT PENARIKAN UANG PALSU PADA ATM."

Meilianasari, Yeni Dwi. "Analisis kepercayaan nasabah pengguna atm." Manajemen Bisnis 2, no. 1 (2013).

Mokoginta, Megi. "Perlindungan Nasabah Bank Dari Kejahatan Pembobolan Atm Menurut Uu No. 8 Tahun 1999 Tentang Perlindungan Konsumen." Lex Privatum 4, no. 6 (2016).

Muryatini, Ni Nyoman. "Perlindungan Hukum Bagi Nasabah Pengguna Anjungan Tunai Mandiri (ATM) Dalam Sistem Perbankan di Indonesia." Jurnal Magister Hukum Udayana (Udayana Master Law Journal) 5, no. 1 (2016): 119-130.

Nurdin, Aad Rusyad. "KAJIAN PERATURAN PERLINDUNGAN KONSUMEN DI SEKTOR PERBANKAN." Jurnal Hukum \& Pembangunan 48, no. 2 (2018): 299-322.

Prabawa, Ida Bagus Eddy, and Gede Putra Ariana. "LEMBAGA PERLINDUNGAN HUKUM BAGI NASABAH BANK PENGGUNA AUTOMATED TELLER MACHINE (ATM).

Putra, A., Dahana, Cokorda. "Perlindungan Hukum Terhadap Rekening Nasabah Bank Dalam Perjanjian Penggunaan Anjungan Tunai Mandiri (ATM) Pada Bank Negara Indonesia (BNI) Cabang Teuku Umar Denpasar." Kertha Semaya 5, No.1 (2016)

Slamet, Sri Redjeki. "Tuntutan Ganti Rugi dalam Perbuatan Melawan Hukum: Suatu Perbandingan dengan Wanprestasi." Lex Jurnalica 10, no. 2 (2013): 18068.

Suherman, Suherman. "Upaya Mediasi dalam Penyelesaian Sengketa di Lembaga Perbankan." ADHAPER: Jurnal Hukum Acara Perdata 4, no. 1 (2018): 109-122.

Sumbodo, Mugiatno, and Jafar Octo Fernas. "SKIMMING, CARA KERJA DAN PENCEGAHAN PADA ATM." IKRA-ITH TEKNOLOGI: Jurnal Sains \& Teknologi 3, no. 2 (2019): 11-16.

Wintara, I., N. Dharmawan, and N. Purwanti. "Mekanisme Pencegahan Kerugian dan Hak Nasabah Terkait Penggunaan Kartu Anjungan Tunai Mandiri (ATM)." Kertha Semaya: Journal Ilmu Hukum 7, no. 5 (2019): 1-14.

Witasari, Aryani, and Aris Setiono. "Perlindungan Hukum Pengguna Jasa electronic Banking (e-banking) Di Tinjau Dari Perspektif Hukum pidana di Indonesia." Jurnal Pembaharuan Hukum 2, no. 1 (2016): 126-137. 


\section{Website}

Bayu Galih Permana, 2019, “Duit Buat Bayar Kuliah Ludes Di ATM, Cerita Mahasiswa Korban Ini Menjadi Viral", URL : http://www.hai.grid.id,diakses tanggal 2 Agustus 2019

Yusi Fitria, 2018, "Saldo Terpotong, Uang Tidak Keluar Dari Mesin Tarik Tunai BRI", URLhttp://www.mediakonsumen.com, diakses tanggal 10 Agustus 2019

\section{Peraturan Perundang-Undangan}

Undang-Undang Nomor 8 Tahun 1999 Tentang Perlindungan Konsumen Undang-Undang Nomor 10 Tahun 1998 Tentang Perbankan Undang-Undang Nomor 21 Tahun 2011 Tentang Otoritas jasa Keuangan Peraturan Otoritas Jasa Keuangan Nomor 1/POJk.07/2013

Surat Edaran Bank Indonesia Nomor. 14/17/DASP Tentang Penyelenggaraan Kegiatan Alat Pembayaran dengan Menggunakan Kartu (APMK)

Surat Edaran Otoritas jasa Keuangan Nomor 2/SEOJK.07./2014 